\title{
"WHAT HAVE WE LEARNED ABOUT THE CONSEQUENCES OF THE COVID-19 PANDEMIC?" - INTERNATIONAL SCIENTIFIC SYMPOSIUM ORGANIZED IN TUZLA IN BOSNIA-HERZEGOVINA
}

\author{
Osman Sinanović ${ }^{1,2,3}$, Izet Pajević ${ }^{1,3}$, Mevludin Hasanović ${ }^{1,3}$ \& Miro Jakovljević ${ }^{3,4}$ \\ ${ }^{1}$ Medical Faculty, University of Tuzla, Tuzla, Bosnia and Herzegovina \\ ${ }^{2}$ Medical School, University Sarajevo School of Science and Technology, Sarajevo, Bosnia and Herzegovina \\ ${ }^{3}$ International Academy of Science and Arts in Bosnia and Herzegovina, Sarajevo, Bosnia and Herzegovina \\ ${ }^{4}$ School of Medicine, University of Zagreb, Zagreb, Croatia
}

\section{INTRODUCTION}

Infection with the new coronavirus (SARS-CoV-2) was first registered in December 2019 in China, and then later spread rapidly to the rest of the world. On December 31, 2019, the World Health Organization (WHO) informed the public for the first time about causes of pneumonia of unknown origin, in the city of Wuhan (Hubei Province, China), in people who were epidemiologically linked to a seafood and wet animal wholesale local market in Wuhan. Coronavirus disease, called COVID-19 (Coronavirus disease 2019), after China quickly spread to most countries in the world, and the WHO on March 11, 2020, and declared a pandemic with this virus. So we have been in a pandemic for more than 19 months. After the first knowledge about the consequences of infection with the SARS-CoV-2 virus, it turned out that it attacks not only the lungs but also other organs (multiorgan disease) and that many infected people cannot survive the infection. Not just the elderly. Unfortunately, we have recently been confronted with new mutations of this virus that have been registered in our region as well. Furthermore, there are significant consequences for the body even after the infection is "overcome“ and it is concluded that we are no longer positive for the virus (Sinanović et al. 2020).

Having in mind the long-visible various consequences for the health of the COVID-19 pandemic, which has been going on for 19 months, it was necessary to announce itself as an International Academy of Sciences and Arts in Bosnia and Herzegovina (IANUBIH) with one scientific symposium. Therefore, IANUBIH with its' Department of Medical Sciences in cooperation with the University Clinical Center Tuzla and the Association of Psychiatrists of Tuzla Canton, under the patronage of Government and Ministry for Health of Tuzla Canton, and Medical Chamber of Tuzla Canton organized on October 22-23, 2021 in Tuzla, the first International Scientific Symposium in Bosnia and Herzegovina, which is dedicated to COVID-19 pandemic. Tittle of the symposium was "What have we learned about the consequences of the COVID-19 pandemic?" The symposium was prepared in a hybrid form (part of the lecture was onsite live and part online) and tried to answer the question posed in the title itself through 22 planned lectures and discussions that were conducted accordingly. The consequences of the COVID-19 pandemic on the children and adults (respiratory problems, mother and child during the pandemic, different neurological, cardiac gastrointestinal and mental health disorders) were highlighted together with the health consequences of employees engaged in health care during COVID-19 pandemic as well as rehabilitation during the pandemic, and on the religious life of believers and religious communities.

\section{HEALTH CONSEQUENCES}

The President of IANUBIH, academician Asim Kurjak (Zagreb/Sarajevo), in his lecture with tittle "Is the COVID-19 pandemic the end of happy globalization - what was the scientific response?", emphasized that "taking into account everything we have learned about the SARS-CoV-2 virus so far it comes as a surprise that there hasn't been a more intense scientific debate on whether the blind lockdown model, implemented by most national governments, was truly an appropriate response to the challenges posed by the pandemic. Today, when we know more about the transmission modes of SARS-CoV-2 (primary mode is by respiratory droplets) as well as how dangerous it truly is (much less than previously thought), it is time to reassess the first radical epidemiological reactions. This needs to be done not to accuse someone of mistakes, but in order to plan future action. It is clear that in the beginning numerous countries opted for radical epidemiological measures because we didn't have enough information about the COVID-19 pandemic but now the time has come to ask the questions about the weirdly mingled responsibility of politicians and epidemiologists who persist in scaring the populace with threats of the virus without considering the general consequences. Individuals who bravely provoke the world scientific community by insisting on a discussion based on data and not assumptions are actually very rare" (Kurjak 2021). 
"International critical care collaboration during COVID-19 pandemics" was tittle of the lecture of Professor dr. Ognjen Gajić, from Mayo Clinic, Rochester, Minnesota, USA. In short, in his online lecture, he sent several important messages about the need for cooperation between health care providers, both in the United States and the countries of the former Yugoslavia and beyond, in order to fight the COVID-19 pandemic more successfully. Namely, Professor Gajić, starting with fact that COVID-19 pandemics brought an unprecedented number of critically ill patients worldwide, and that challenges with hospital strain and misinformation pandemics further compromised patient care and outcomes, accentuated: "The development of large collaborative research registries has highlighted the fact that high-quality supportive care is the most important modifiable outcome determinant of COVID-19 critical illness. Mayo Clinic's CERTAIN program (Checklist for Early Recognition and Treatment of Acute Illness and Injury) is a virtual education and quality improvement program focused on a standardized approach to the critically ill with the goal to maximize the quality of life and, when appropriate, quality of dying using a compassionate, humane approach to patient care. During the pandemics, CERTAIN has been used to support clinicians in busy Intensive care units (ICUs) in the USA, and with the support of the WHO office in Sarajevo, has also helped with rapid knowledge sharing with health care workers in the countries of former Yugoslavia" (Gajić 2021).

Corona virus (CoV) discovered during the 1960s and its association with illness of varied intensity. The most severe type resulting in large-scale pandemics in the past are the SARS (in 2002-2003) and Middle East respiratory syndrome (MERS) (in 2012)(Cheng et al. 2007). CoV are RNA viruses of the subfamily Coronavirinae. They belong to the family Coronaviridae and the order Nidovirales (nido Latin for 'nest'). In view of taxonomical classification, SARS-CoV-2 (COVID-19) is one among many other viruses in the species, SARSrelated CoV. However, SARS-CoV and SARS-CoV-2 vary in terms of disease spectrum, modes of transmission and also diagnostic methods (Gorbalenya et al. 2020). The main factors involved in viral pathogenesis of 2019-nCov are spike 1 subunit protein, priming by transmembrane protease serine-2 (essential for entry and viral replication), ACE2 receptor-2019-nCov interaction and down regulation of ACE2 protein (Umakanthan et al. 2020).

Professor dr. Semira Galijašević (Sarajevo) discussed on the "Role of oxidative stress in SARS-CoV-2 and possible mechanism" (Galijašević 2021). She stressed that "there are still many unknowns and competing hypothesis in an attempt to explain exact behavior of the virus. Some of the major unknowns are the number of angiotensin converting enzyme 2 (ACE2) receptors needed to bind each spike protein, number of spikes to gain entry to the cells. So far, 332 interactions between SARS-Co2 and human proteins have been detected. The latest scientific data implicated association of oxidative stress with changes found in patients with COVID-19, such as the initiation and the amplification of the cytokine storm, coagulopathy, and cell hypoxia. Influx of ROS and a high oxidative stress was implicated as a potential cause of lymphopenia and $\mathrm{T}$ cell suppression in COVID-19. High glucose and also hypoxia /reperfusion happening upon ventilation of COVID-19 patients leads toward another increase in ROS, thus promoting further tissue injury. In a structural manner, oxidative stress can cause oxidation of the cysteine residues on proteins of both the virus and ACE2 to form disulfide bonds that in turn increase the affinity of the SARSCoV-2 for ACE2, thereby amplifying COVID-19 pathogenesis. The complexity of the SARS-CoV-2 activity on a cellular level, and cascade of events leading towards serious tissue injury that clearly involves oxidative stress demands detailed research and detection of exact mechanistic pathways in order to develop appropriate therapies".

Already at the beginning of the COVID-19 pandemic, it was clear that this is primarily a respiratory disease, but it was soon realized that it is at the same time a multi-organ disease (Sinanović et al. 2020, Sinanović 2021).

Professor dr. Jasmina Smajić (Tuzla) in her lecture "COVID-19: respiratory disorders" outlined the most important aspects of respiratory disorders in COVID-19 patients. She stressed: "The most common clinical presentation of severe COVID-19 is acute respiratory failure consistent with the acute respiratory distress syndrome. Airway, lung parenchymal, pulmonary vascular, and respiratory neuromuscular disorders all feature in COVID-19. Viral pneumonia is the most frequent serious clinical manifestation of COVID-19, prominently featuring fever, cough, dyspnea, hypoxemia, and bilateral infiltrates on chest radiography. Dry cough is more common than a productive cough. Dyspnea appears after a median time of 5 to 8 days. Severe hypoxemic respiratory failure consistent with the Berlin definition of the acute respiratory distress syndrome (ARDS) occurs in a significant proportion of patients with COVID-19 pneumonia. Patients who require mechanical ventilation have a high risk of death". In the continuation of the lecture, she explained the possible mechanisms of action of the virus in the respiratory tract: "After entering and replicating within the nasal mucosa, SARS-CoV-2 travels to the conducting airways, where it triggers an immune and inflammatory response, manifesting in clinical signs and symptoms of COVID-19. Although SARS-CoV-2 infection often begins in the upper airway epithelium, in a subset of patients, the virus infects or injures the alveolar epithelium diffusely, 
resulting in markedly impaired gas exchange and respiratory failure. SARS-CoV2 infection of endothelial cells, which might occur from luminal or alveolar interstitial side, triggers endothelial release of cytokines, which cause increased capillary permeability, thereby allowing adhesion and extravasation of neutrophils and monocytes into the alveolar interstitial space. Neutrophils, and macrophages secret a multitude of cytokines, procoagulants, and complement, which promote viral attack and clearance but which induces further vascular injury enhancing the risk for thrombosis. COVID-19 affects all components of the respiratory system, including the neuromuscular breathing apparatus, the conducting airways, the respiratory airways and alveoli, the pulmonary vascular endothelium, and pulmonary blood flow" (Smajić 2021).

Intending to discuss various aspects of the health consequences of the COVID-19 pandemic on health we had two lectures dedicated to pregnant women and newborns, as well as children.

Professor dr. Milan Stanojević (Zagreb) had a very interesting lecture titled "Mother and newborn during the COVID-19 pandemic: between Scilla and Charybdis", in which he emphasize the importance of vaccinating pregnant and breastfeeding women, who should not be advised but recommended to be vaccinated, and importance of contact between mother and newborn immediately after birth. He stressed: "In maternal and child health, the pandemic has brought numerous misconceptions that are inconsistent with the natural laws governing the mother-child relationship, which will certainly leave unforeseeable consequences, including those relating to the mental and overall health of future and present generations. Therefore, it could be said that medicine (along with politics) in its recommendations regarding the protection of maternal and child health during the COVID-19 pandemic was and still is between Scylla and Charybdis" (Stanojević 2021).

Academcian Senka Mesihović-Dinarević (Sarajevo) in the lecture titled „Postcovid-19 in children - evaluation of immunological and coronary artery status", presented the results of research conducted on 70 children /previously healthy or with no pre-existing heart disease/ from Sarajevo with positive postcovid history (Mesihović-Dinarević et al. 2021). The aim of this study was to evaluate the knowledge on SARS-CoV-2 infection, epidemiology, and transmission, the associated clinical presentation including immunological and cardiovascular status in postcovid children. She concluded that practitioners should consider the possibility of COVID-19 in children with atypical symptomatology and positive or suspicious epidemiological survey, paying special attention to immunological and coronary artery status (Mesihović-Dinarević 2021).

Professor dr. Petar Kes (Zagreb) spoke on acute kidney injury in patients with COVID-19 ("COVID-19:
Nephrological disorders"). His main messages were: "Acute kidney injury (AKI) is a common finding in patients with coronavirus disease 2019 (COVID-19), and it is associated with long-term hospital treatment, more frequent admission to intensive care units (ICUs), and higher mortality compared with COVID-19 patients without kidney disease. Moreover, the mortality rate is directly proportional to the severity of AKI. The pathophysiology of COVID-19 associated AKI could be related to specific and unspecific mechanisms. COVID-19 specific mechanisms are direct cellular injury resulting from viral entry through the angiotensin converting enzyme 2 receptor, which is highly expressed in the kidney, an imbalanced renin-angiotensin-aldosterone system (RAAS), severe respiratory failure, proinflammatory cytokines elicited by SARS-CoV-2 infection, coagulopathy, microangiopathy, and collapsing glomerulopathy. Nonspecific mechanisms include hemodynamic alterations, high levels of positive end-expiratory pressure in patients requiring mechanical ventilation, sepsis, hypovolemia, rhabdomyolysis, and administration of nephrotoxic drugs. Today, we do not know enough about the prevention and management of COVID-19. Treatment of AKI includes general management, pharmacological management of COVID-19, hemodynamic and volume optimization, renal replacement therapy, and other extracorporeal organ support. As of now, the long-term prognosis is unknown. However, it may be safe to speculate that prognosis will be associated with the etiology of AKI. Patients with thromboembolic complications and collapsing glomerulopathy may develop a more severe degree of chronic kidney disease compared to those with other types of renal injury (e.g., acute tubule-interstitial nephritis). Early studies suggest that about one-third of patients who survived AKI caused by COVID-19 will remain dialysis-dependent” (Kes 2021).

"The laparoscopic surgery: technique, ergonomic and specifies in the time of COVID-19 pandemic" was title of Professor dr. Šefik Hasukić (Tuzla) lecture. The main messages of this lecture were: "The application of laparoscopic surgery at the time of COVID-19 infection requires some answers that we do not yet have. Difficult visualization of the operative field, which is otherwise present during laparoscopy, is further complicated by the use of special clothing, visors, and glasses in COVID-positive patients. Also, the insufflation of $\mathrm{CO}_{2}$ into the abdomen and its losses can potentially cause infection of the surgical personnel. Therefore, the application of laparoscopic surgery in emergency operations in COVID-positive patients is not an advantage over open surgery" (Hasukić 2021).

Doc. dr. Emir Fazlibegović (Mostar) in his lecture titled "COVID-19: cardiologic disorders", presented the most important facts related to the cardiac disorders associated with the COVID-19 pandemic: The association between COVID-19 and acute myocardial in- 
farction (AMI) is interpreted as impaired immunity with enhanced inflammatory response and development of endothelium with procoagulant disorders such as thrombosis and thromboembolism with sequelae on the heart, brain, pulmonary and peripheral arteries. Endothelial dysfunction develops with myocardial damage with the instability of atherosclerotic plaque, its fissure and rupture, and AMI. Comorbid conditions such as hypertension, diabetes, hyperlipidemia, and kidney disease further exacerbate the severity and outcome of the disease. Air pollution also significantly contributes to the clinical picture of the disease and complicates COVID-19 infection with the development of cardiovascular complications of the AMI, with cardiac decompensation, malignant cardiac arrhythmias, myocarditis, and pericarditis that contribute to clinical severity and mortality. There was a lower influx of patients to cardiology departments and coronary units and emergency services during the epidemic wave by $30-48 \%$ depending on the region-country in the world, but also an increase in the severity of the clinical picture and higher mortality from cardiovascular disease. The reasons for this phenomenon are mostly unknown. It is assumed that it is a matter of fear, "lockdown", selfisolation, and delay in attending the doctor, which prolongs the time of ischemia and loses the "golden hour" to reperfusion of AMI patients, which is also contributed by anti-epidemic measures with PCR testing and personal protection measures. Staff in catlaboratories which prolong the door-balloon time and thus more serious heart damage" (Fazlibegović 2021).

Gastrointestinal complications in COVID-19 patients ("COVID-19: gastrointenstinal tract") were also presented during second day of symposium, by Professor dr. Milenko Bevanda (Mostar). He stressed that " $12 \%$ of patients with COVID-19 have gastrointestinal symptoms, and in $40.5 \%$ of all patients SARS-CoV-2 can be isolated from stool. Patients with COVID-19 have significant changes in the fecal microbiome. Useful commensals are exhausted, and the number of pathogenic bacteria is increasing. Pharmacological treatment of the underlying disease also contributes to these changes. Patients with these changes may develop gastrointestinal symptoms such as nausea, vomiting, discomfort, or abdominal pain and diarrhea. Intestinal dysbiosis persists even after cure from COVID-19 and cessation of respiratory symptoms. These changes can lead to reduced resistance to pathogens such as $\mathrm{C}$. difficile and to the development of diarrhea associated with $\mathrm{C}$. difficile and colitis... Liver injury is more common in the more severe form of COVID-19 and can occur as a direct action of the virus, drug-induced, and immunemediated. High ALT values, low platelets and albumin are associated with higher mortality rates. Patients with advanced chronic liver disease have an increased risk of infection due to immune dysfunction. Patients with cirrhosis, nonalcoholic fatty liver disease and hepatocellular carcinoma are at risk for more severe disease, while patients with viral hepatitis generally do not have an increased risk of developing more severe forms and consequently have a higher hospitalization rate, admission to intensive care unit and COVID-19 related deaths than general population... Patients with cirrhosis and COVID-19 have a high rate of liver decompensation, acute-chronic liver failure, and death from respiratory failure after severe SARS-CoV-2 infection and should be a priority for vaccination (as are all other vulnerable groups) (Bevanda 2021).

Several lectures were devoted to neurological disorders. Professor dr. Vanja Bašić-Kes (Zagreb) talked about COVID-19 in neurology ("COVID-19: Neurological disorders"). Namely, "as the COVID-19 pandemic progresses, the number of reports of neurological manifestations of the disease is increasing (thousands of patients have been reported to date). Neurological manifestations of the disease may be due to the direct and indirect effect of SARS-CoV-2 on the nervous system as a neurological complication of the systemic effect of COVID-19, as well as immune-mediated diseases. Furthermore, patients have been described in whom an immune-mediated neurological disease (e.g. Guillian-Barre syndrome) or acute disseminated encephalomyelitis has developed after overcoming SARSCoV-2 infection (SARS-CoV-2 can enter the nervous system through the blood-brain barrier, infected leukocytes or retrograde transport along cranial or peripheral nerves. The innate immune response to viral infection and consequent inflammation can damage nerve tissue, as in the case of acute encephalopathy syndrome caused by influenza. Pathologically adaptive immune responses include damage caused by cytotoxic $\mathrm{T}$ cells and antibodies directed to host tissue in the central or peripheral nervous system. The latter can be caused by molecular mimicry between the pathogen and the host epitope, or tissue damage can result in a failure of tolerance to its own antigens. Infection with SARSCoV-2 can cause damage to blood vessels by direct infection or immune-mediated vasculitis. Furthermore, the virus can activate vascular endothelium with consequent inflammation associated with inappropriate lymphocyte and macrophage excessive activity and thrombotic microangiopathy" (Bašić-Kes 2021).

Professor dr. Slobodan Apostolski and dr. Slađana Knežević-Apostolski (Beograd) shared their experiences in monitoring patients with myasthenia gravis during COVID-19 pandemic ("COVID-19 and Myasthenia gravis"). They followed 172 patients with myasthenia gravis at the outpatient neurological clinic between January, 2020 - August, 2021 and performed retrospective analysis of the clinical course in 30 patients infected with SARS-CoV-2. They concluded that myasthenia gravis (MG) patients with COVID-19 
requiring hospitalization revealed an intensive care unit admission rate of only $3.3 \%$, with no mortality. Most of MG patients infected with SARS-CoV-2, had moderate clinical presentation with a hospitalization rate of $23.4 \%$, and $73.3 \%$ were asymptomatic with mild COVID-19. They think that can be explained by continuous immunosuppression before and during infection with no deterioration of MG (Apostolski \& Knežević-Apostolski 2021).

Academician Osman Sinanović (Tuzla/Sarajevo) spoke on "Association of sense of smell and taste disorders with SARS-CoV-2 infection": There are a large number of reports of different incidence of anosmia and ageusia in different countries around the world and they range from a wide range of 20 to $98 \%$ of patients with COVID-19, with the most common reports of high percentages $(>80 \%)$ being the primary symptom in approximately $12 \%$ of patients. These disorders are more common in the elderly and somewhat more common in women, but are not uncommon in the young and children. They usually last for a short time, less than a month, but a significant number of infected people have a disorder that lasts for months. For now, it is more or less possible only to speculate the mechanism of anosmia formation in SARS-CoV-2 patients. Anosmia can generally be divided into a conductive and sensorineural olfactory loss. Conductive loss occurs when we have impaired airflow through the nose and this disorder is usually reversible after nasal obstruction recovers. Sensorineural olfactory loss involves olfactory epithelial dysfunction and may be permanent or functional recovery may take longer. Several possible mechanisms that may be in the background of SARSCoV-2 anosmia, and lead to isolated anosmia or in combination with other symptoms, have been considered. According to one theory, the virus binds to angiotensin converting enzyme 2 receptors in the nasal epithelium and causes degeneration of the nasal mucosa, as well as subsequent inflammation and damage to the nerve receptors responsible for the olfactory. The second hypothesis, currently the most widely accepted, suggests a direct effect of the virus on the central nervous system based on the natural clinical course of the sense of smell disorder, the treatment strategy can be focused on the one that targets the acute phase and the one that targets the chronic phase. Namely, the initial viral attack can be accompanied by damage to synaptic plasticity. Based on the natural clinical course of the sense of smell disorder, the treatment strategy can be focused on the one that targets the acute phase and the one that targets the chronic phase. For a virus that causes inflammation, local or systemic corticosteroids may be useful in the acute phase of olfactory dysfunction. The main characteristic of synaptic plasticity is the possibility of synaptic modification induced by activity or learning, which may partly explain why olfactory training is an effective therapy for this disorder (Sinanović 2021).
"COVID-19 and Parkinson's disease" was title of lecture delivered by Professor dr. Zlatko Trkanjec (Zagreb). He stressed that, "compared with controls, patients with Parkinson's disease (PD) during the SARS-CoV2 virus epidemic had significantly increased levels of stress, depression, and anxiety and reduced quality of life, and a significant decline in physical activity during locking. PD patients have outcomes of COVID-19 infection that do not differ significantly from patients without PD of similar age and with similar comorbidities. Motor and non-motor symptoms worsen during lockdown due to the COVID-19 epidemic in PD patients not infected with the SARSCoV2 virus. PD patients with COVID-19 often had new or worsening of existing motor and non-motor symptoms, requiring changes in medication in one third of cases. The most significant motor problems were urinary problems and fatigue". Furthermore, he stressed "The SARS-CoV-2 virus enters cells via the angiotensin converting enzyme 2 (ACE2) protein. ACE2 proteins are bound to the cell membrane and are found in numerous organs, endothelial cells of arteries and veins, smooth muscle cells in arteries, neurons, and glial cells in the cerebral cortex, striatum, hypothalamus, and the brainstem. Dopamine neurons in the mesencephalon have high levels of ACE2 receptors. The SARS-CoV-2 infection could induce cytotoxic aggregation of proteins, including $\alpha$-synuclein, which could function as an antiviral factor within neurons, as shown by increased $\alpha$-synuclein expression after acute West Nile virus infection. Rodents infected with H5N1 influenza show CNS microglia activation and abnormal phosphorylation of $\alpha$-synuclein causing loss of dopaminergic neurons in the pars compacta of the substantia nigra. Accumulation of $\alpha$-synuclein after SARS-CoV-2 infection can lead to changes in $\alpha$ synuclein and accelerate neurodegeneration. Thus, the virus could initiate and/or accelerate neurodegeneration. COVID-19 is a new disease, and PB is known to develop slowly over years and decades, so any suggestion that the SARS-CoV-2 virus causes PB can only be a guess as to what may happen in the future. There are probably some links between the SARS-CoV2 virus and $\mathrm{PB}$, but so far there is no evidence that this virus could in the future contribute to the increased incidence of PD" (Trkanjec 2021).

Professor dr. Mirsad Muftić (Sarajevo) spoke on "Rehabilitation during the COVID-19 pandemic". He particularly emphasized the need of rehabilitation of post-covid patients: "Rehabilitation of post-covid patients takes place according to an individual plan depending on the severity of the clinical picture of the patient's sex and age, comorbidity, and complications present. The rehabilitation team consists of a doctor specializing in physical medicine and rehabilitation, physiotherapist, pulmonologist, psychologist, and health professionals from other fields, depending on the clinical picture of patients" (Muftić 2021). 


\section{CONSEQUENCES FOR RELIGIOUS LIFE AND MENTAL HEALTH}

One of the separate sessions was dedicated to the consequences of the COVID-19 pandemic on the religious life of believers and religious communities in $\mathrm{BH}$ and in general with views from the Islamic, Catholic and Orthodox perspectives.

Dr. Sead Seljubac (Tuzla) had a very interesting and intriguing title of his lecture, "COVID-19 pandemics: a test or punishment - Islamic perspective", which essentially hints at its content. At the beginning of the lecture, he pointed out: "A believer believes that the Almighty Creator of all worlds has not left those worlds without His control and governing, and believes that they have not been cast adrift and left to chance. He ordered the worlds in the way that $\mathrm{He}$,blew in him of His spirit"(15:29; 38:72). A man functions as a bland of body and soul, likewise, all the other worlds and creatures manifest their liveliness in different ways. However, even non-living creatures have their 'life'. It is woven into the laws of physical worlds, which enable them to be, to exist. Of course, Allah the Exalted has not 'imprisoned' His powers by His own laws. He does what He wants (3:40), as the Qur'an claims. While all the mentioned elements are in harmony, the world is ruled by order and peace, people are healthy, animals are satisfied and plants are happy. Every single deviation from the 'Godgiven' function results in malfunctioning and disorder, which leads to a chain reaction and causes bigger or smaller consequences. It can be called a mess, or, depending on the circumstances, a disaster, a disease, state of war, or restlessness... When a man starts treating the world in a wrong way, either unconsciously or intentionally, is a sign of rebellion against God, and that is when we get global warming, world, regional or local wars, natural disasters, or simply failing to isolate or 'close down the region where there is an outbreak of pandemics... It is unreasonable to reject our own change and expect God to change His laws. That will not happen. Our state will change for the better only when we are ready to change ourselves in a positive sense. Therefore, looking from the Islamic perspective, the most appropriate phrase which we can use to name this trouble that we are living is God's sign. The sign which we need to read and learn from. For change. To be better than we are. Towards Him and towards the world".

In the second part of the lecture, dr. Seljubac talks about possible active steps towards preventing future similar challenges: What are Islamic principles related to prevention in case of a contagious disease outbreak? According to some historians, God's prophet Muhammad, peace be upon him (p.b.u.h), came back from the battle of Tabouk and, in relation to the plague epidemic which spread in Syria at the time, he told his companions: „When you hear about an outbreak of plague in a land, do not go there. If plague breaks out in a country where you are staying, do not leave that place by any chance". The followers of the beloved prophet did what he instructed them to do in this situation. This makes it mandatory for us to quarantine as a way of prevention. The final decision is on experts and decision-makers. That is our way and our duty. Human, civic and religious duty. The next principle in Islam is our duty to save and protect our health, as well as to look for a cure for the existing diseases. The Prophet Muhammad, peace be upon him - p.b.u.h., invited people to take care of their health emphasizing that God has given a cure for every disease, and he also invited Muslims to keep looking for the cure. That is why the Grand Mufti in one of his sermons (August 2021), inviting people to get vaccinated, pointed out the following: "The first revealed verses in the Qur'an were: Read in the name of your God who created. (96:1). He who doubts the knowledge given to people also denies God's Revelations. Leave your doubts without proves aside, because that is a sin". And the third principle is the principle of respecting people of knowledge. The Qur'an orders us to ask those who know if we do not know (21:7). Experts deserve respect because that way we pay respect to knowledge and science in general. That is our duty as believers. On the other hand, the medical profession has an obligation to justify that respect in the most appropriate way, by putting the maximum effort into finding the best cure for this as well as any other disease. And God has given a cure for every disease. That is why we should walk the way we have chosen. Optimistically. The way of positive changes. The wise Rumi said: "That is your way, and only yours. Others can walk with you, but no one can walk instead of you" (Seljubac 2021).

Academician Mijo Nikić (Zagreb), Catholic priest and professor at the Catholic theological faculty in Zagreb, spoke about COVID-19 pandemic from the perspective of Catholic theology ("The COVID-19 pandemic - call to conversion and return to God: a view from the perspective of Catholic theology"). A summary of his lecture is as follows: "The whole world has been in a crisis situation for a long time. Fear reigned on a global scale. The corona virus identified as COVID-19, sneaks in unnoticed all around us. It does not act selectively, but equally attacks old and young, good and evil, believers and unbelievers. In such a situation, many feel frightened and ask: where is God in the corona virus pandemic? One interprets this virus pandemic that has struck us as God's punishment for sins committed; others as a consequence of sins committed by their ancestors; the third accepts suffering as an inevitable destiny. According to the teachings and beliefs of the Catholic Church, God wants only the good of man, moreover, he wants only what is best for man and his eternal salvation. Therefore, when a man in the gifted freedom turns away from God, God still remains faithful to his promises. God never forgets man, but calls him to conversion in internal and external stimuli 
in ways known only to him. Therefore, we view this pandemic, like all other adversities in our lives, in the light of a faith that calls us to true conversion and challenges us to grow more and more as people and as believers who put God first in their lives and who believe that, to those who love God, God Himself turn everything to good. The first words of Jesus according to Mark's Gospel read: "The time is fulfilled, and the kingdom of God is at hand. Repent and believe the gospel (Mark 1:15). To convert means: to come to oneself and return to one's God. To come to oneself means to become aware of the meaning of one's existence in this world, to discover the right path that leads to eternal life. And to return to God means to put God first in our lives and to believe in his love in Christ Jesus, and to open ourselves completely to the Holy Spirit. God calls us 365 times in the Bible: "Do not be afraid! I am with you! " That truth is what we need most now!" (Nikić 2021).

Through his lecture entitled "COVID-19 pandemic shepherd challenges for Orthodox church", MSc Srđan Radmanović (Bijeljina), Orthdox priest presented his views on the pandemic from Orthodox perspective: "The consequences of the pandemic are also present in the sphere of religious life, both of the individuals and the religious community to which they belong to. One of the main theological fundaments is that a human being is a dialogical being that consists of several different entities that form its identity and value system, which produce reactions and behavior patterns. The formation of one's identity is influenced by different factors. During the pandemic, it became apparent that the availability of information through the media and the influence of social networks play a decisive role. All this enters into the church being of each individual and responds to the challenges set in accordance with personal sensibility. The Serbian Orthodox Church has also faced certain challenges, particularly ones of a pastorals nature. The reactions of the Church demonstrated a high level of both individual and collective social responsibility while striving to remain faithful to its fundamental beliefs. This is supported by the decisions of the highest Church governing authorities, as well as individual Episcopal, who called to respect of all recommended measures that had been adopted by the Crisis Committee, i.e. that the whole Church life had to conform to the measures of the state of emergency. Those measures and recommendations adopted by the Church provoked reactions within the Church community itself. Due to the varying scope of restrictions imposed, and the inability to achieve full sacramental life, the Church and its members faced certain pastoral challenges. Different reactions followed. They ranged from full acceptance of all measures to the absolute rejection of any measures as something that does not resonate with the confession of the Orthodox Church.
The authenticity of religion and the authority of Church institutions were called into question. And, in some sense, the identity crisis was emphasized. The above favored the creation of free space for the activation of fundamentalist individuals and groups within the Church. Simultaneously, non-theological and para theological attitudes came to the forefront in an extraordinary way. Due to these reactions, the Church was in a situation where the depersonalization of a man occurred within the Church itself. As a result, we had a situation where certain individuals and groups lost their sense of sacramental collective responsibility for the world and the individuals. Besides these challenges, a very difficult shepherd challenge was put before the Church. That was the actualization of possible segregation within the societies themselves, segregation between those who have been vaccinated and those who have not. Issues of positive discrimination and protection of public health, in this case, became a pastoral challenge for the Church, as the guardian of the individual's integrity, particularly for its members, as a certain obstacle to maintaining a complete sacramental life and thus achieving identity. Despite all these pastoral challenges, the Church has continued to contribute during this crisis. Besides the fact that its extremely strong social impact has been proved, alongside its ability to contribute to respecting the recommended measures, the contribution of the Serbian Orthodox Church is also reflected in making all its resources available. Therefore, it is important to stress once again that the Church continues to have its extremely strong social role, which is not diminished by the existence of these pastoral challenges. It seems that the necessity of a more active dialogue between the Church and other socially important factors will be of great importance in the upcoming post-Covid period, no matter when it starts. The consequences of the pandemic are partly known to us. In this sense, we must say that, despite the evident pastoral challenges, the Church will continue to carry out its mission of salvation by emphasizing the dialogue nature of man, as the only possible postulate in finding solutions to all the challenges posed before all of us during the pandemic" (Radmanović 2021).

In the definition of health we know that it is not only the absence of disease but also the overall mental but also spiritual well-being (Jadad \& O'Grady 2008, Anonymous 2009, Leonardi 2018).

With this fact in mind the impact of the COVID-19 pandemic on mental health is part of the overall mosaic and certainly related to people's religious feelings as well (Jakovljević et al. 2020). In this context, we emphasize as a very important lecture of the President of World Psychiatric Association (WPA), Professor dr. Afzal Javed (London) "Mental health challenges during COVID-19 pandemic". Professor Javed pointed out " $21^{\text {st }}$ century is witnessing rapid global changes 
along with a major shift in current thinking about shifting priorities in health and social care. Adding to its high infectivity and fatality rates, the COVID-19 is leading to consequential universal health impacts by causing fear, economic burden, and financial losses. While the effects of severe acute respiratory syndrome coronavirus 2 (SARS-CoV-2) on the nervous system remain unclear, there is no doubt that the COVID-19 pandemic is bad for mental health. Corona-phobia as well as the actual effects of COVID-19 have generated a plethora of psychiatric manifestations across the different strata of the society that have increased a need to revisit current mental health planning. The COVID-19 pandemic is having additional impacts on everyone's lives. There is no doubt that COVID-19, a biomedical disease, has serious physical and tremendous mental health implications due to the rapidly spreading pandemic. In addition to financial impacts, mental well-being is becoming a focus of attention for health professionals, service providers and policy makers dealing with health and social care planning. There may be common reactions to the difficult situation we face but everyone is reacting differently to events and changes in the way that we think, feel and behave" (Javed 2021).

Professor dr. Miroslava Jašović-Gašić and Doc. dr. Tijana Cvetić (Beograd) in their lecture entitled "Mental health challenges during COVID-19 pandemic", gave an overview of the latest knowledge of the impact of COVID-19 inflections on mental health. They pointed out that so far there have been few studies done by type of "face to face", rather than "on line" survey type or by type of doctor's report. In conclusion they stressed the "the studies shown provide evidence for significant symptoms of anxiety, depressive symptoms, post-traumatic stress symptoms, and neurological and psychiatric morbidity in progress, during and 6 months after covid-19 infection, called: post-traumatic syndrome or "late COVID". The risks were highest, but not limited to patients who had severe COVID-19 clinical features. This information can help plan services and identify research priorities. Matching designs, methodology, including potential cohorts needed to confirm and explain these and other discoveries. Until further research and new, useful knowledge, let us remain optimistic and have confidence in science, health care professionals, and the most important vaccines and vaccinations, as well as respect for epidemiological measures" (Jašović-Gašić \& Cvetić 2021).

"Health consequences of employees engaged in healthcare during the COVID-19 pandemic" was the title of a lecture given by Professor dr. Mevludin Hasanović and Professor dr. Izet Pajević (Tuzla). They pointed out: "Some findings identified the following risk factors for COVID-19-related health impact: working in a high-risk department (COVID-19 Clinics and/or departments), inadequate hand hygiene, suboptimal hand hygiene before and after contact with patients, improper PPE use, close contact with patients ( $\geq 12$ times/day), long daily contact hours $(\geq 15 \mathrm{~h}$ ), and unprotected exposure. The most common symptoms identified amongst HCWs were fever, cough, and weakness. Prolonged PPE usage led to cutaneous manifestations and skin damage with the nasal bridge most commonly affected site. Female HCWs and nurses were disproportionately affected. The problems of Bosnia and Herzegovina (BH) as a developing country were both, the lack of funds for the procurement of personal protective equipment (PPE), and its unavailability on the world market. On the other hand, we were witnessed that "some of the strongest health systems in the world have been surprised by the pandemic".... To show the consequences of the COVID pandemic in $\mathrm{BH}$, experienced by health workers who worked during the pandemic, we found it impossible to find the exact data because no institution in $\mathrm{BH}$ has collected data on this important issue. We addressed some institutions from the cantonal to the state level, but the answer is the same, they do not have particular data on the consequences of the COVID pandemic on HCWs in $\mathrm{BH}$. We received exact data according to the information available to the Federation of $\mathrm{BH}$ Medical Chamber that a total of 27 doctors from the Federation of BH (4 women and 23 men) died as a result of the coronavirus infection. In Tuzla Canton $7(1+6)$, in Sarajevo Canton $12(1+11)$, Zenica-Doboj Canton 4 (1 + 3). Central Bosnian Canton 2 (m), HerzegovinaNeretva Canton 1 (m), Bosnian-Podrinje Canton 1 (m). There are no exact data on the number of infected doctors and nurses and technicians from COVID-19 in BH" (Hasanović \& Pajević 2021).

Academician Miro Jakovljević (Zagreb) spoke about "Promotion of the mental health and fighting against COVID-19 pandemic and infodemic". In short: The COVID-19 pandemic is cruel but crucial lesson for the future of humankind and transdisciplinary integrative medicine because it represents very complex events, complex in its origin, its spread, its effects, and its consequences at multiple levels and fields with a big impact on people's mental health. On the other side, the quality of our individual, collective, and public mental health is very important for successfully fighting against the COVID-19 pandemic and infodemic. Positive mental health involves the capacity to 1 . realize our abilities and cope with adverse life events (resilience and antifragility), live a life with a purpose and meaning, and make a positive contribution to our communities; 2 . empathize with others (understand how others think, feel and behave) and mentalize properly (predict actions, intentions, and feelings of others); form positive and creative relationships with others, and feel connected and supported; 3. experience of good faith, hope, peace of mind, and solidarity; 4. practicing freedom by taking responsibility for oneself and for others as 
appropriate. What we need is resilience, coherence, and science in this time of pandemic, not conspiracy theories, blame games, and panic. COVID-19 pandemic and infodemic can be effectively overcome only in the spirit of mutual empathy, respect, trust, and public/ global cooperation sowing the seeds for humanistic self, compassionate society, and empathic civilization, rather than blaming, scapegoating, and xenophobia. Empathy for difference and opening to diversity is the invisible force that holds society and civilization together. The good news from the latest neuroscience research is that empathy, coherence, and resilience can be taught, learned, and cultivated. Fighting the COVID-19 crisis should be our collective hero's journey to better individual, public, and global mental health, compassionate society, and empathic civilization... It is very important to note that some resilience factors may contribute to the development of other resilience factors, and, inconsistency with a cascade model, together they contribute to predicting personal recovery" (Jakovljević 2021). Fighting COVID-19 crisis should be our collective hero's journey to better individual, public and global mental health, compassionate society and empathic civilization (Jakovljević \& Jakovljević 2021).

At the end of the symposium, a book "Norman Sartorius - Talks, Thoughts and Works" (Medcinska naklada: Zagreb, 2021) by Vlado Jukić and Miro Jakovljević was presented. Norman Sartorius is the well-known expert in the field of World Psychiatry and Global mental health and one of the previous presidents of the WPA as well as a senior official of the World Health Organization in the field of mental health. The presentation of the book was moderated by academician Osman Sinanović, and speakers were Professor Afzal Javed (online/London), academician Miro Jakovljević and Professor Norman Sartorius (online/Geneve).

\section{CONCLUSION}

The general assessment of the International Scientific Symposium organized by International Academy of Sciences and Arts in Bosnia and Herzegovina (IANUBIH) and its' Department of Medical Sciences in cooperation with the University Clinical Center Tuzla and the Association of Psychiatrists of Tuzla Canton in term of organization and realization of the lecturers, online (371 participants) and in situ participants (40), organizers, and several media that followed the symposium is that the meeting was very successful. The lecturers were from London/UK (1 lecturer), Mayo Clinic/ Rochester/USA 1 lecturer), Zagreb/Croatia (6 lecturers), Belgrade, Serbia (2 lecturers). From Bosnia and Herzegovina there were 12 lecturers: Sarajevo (2 lecturers), Mostar (2 lecturers), Bijeljina (1 lecturer) and Tuzla (7 lecturers).

After a 19-month pandemic that unfortunately still lasts, we have more knowledge about the pathogenesis of COVID-19 and the spread of the SARS-CoV-2 virus. We also know more about the overall health consequences that clearly indicate that this is not just a disease of the respiratory system but a multi-organ disease. While the effects of severe acute respiratory syndrome coronavirus 2 (SARS-CoV-2) on the nervous system remain unclear, there is no doubt that the COVID-19 pandemic is bad for mental health. At the same time many aspects of human life are affected such as e.g. religious life. The economy is affected, the usual way of education in general, especially in areas where practical work is necessary.

The COVID-19 pandemic is cruel but crucial lesson for the future of humankind and transdisciplinary integrative medicine because it represents very complex events, complex in its origin, its spread, its effects, and its consequences at multiple levels and fields with a big impact on people's mental health. On the other side, the quality of our individual, collective, and public mental health is very important for successfully fighting against the COVID-19 pandemic and infodemic.

The response of science to the challenges of this pandemic is the relatively rapid definition of safe and effective vaccines, as well as the dedicated work of a large number of scientists to define an effective cure. Unfortunately, vaccines are not equally available among poor and rich countries. Furthermore, the number of vaccinated is still not enough, and we know that only by adequately vaccinating a sufficient number of people on the planet can we stop and / or control the spread of the virus. The scientific community in every environment as well as in the world in general must be mobilized at full capacity in order for this planetary trouble to be overcome. And state administrations should have more hearing and coordination with the scientific and professional potentials they have in their fields.

The COVID-19 pandemic, as well as the misinformation infodemic about it, has shown us that what humankind needs now more than ever is collective resilience, antifragility, empathy, trust, coherence, collaboration, and science in its purest form. Fighting COVID-19 crisis should be our collective hero's journey to better individual, public and global health, compassionate society and empathic civilization.

\section{Acknowledgements: None.}

\section{Conflict of interest: None to declare.}

\section{Contribution of individual authors:}

Osman Sinanović: concept and design of article, literature searches, writing manuscript, approval of final version.

Izet Pajević, Mevludin Hasanović, Miro Jakovljević: comments on the concept of article, literature searches, writing some parts of manuscript, approval of the final version. 


\section{References}

1. Anonymous: What is health? The ability to adapt. Lancet 2009; $373: 78$

2. Aposotolski $S$ \& Knežević-Apsotolski S: COVID-19 and Myasthenia gravis. In: Sinanović $O$, Hasanović M, Pajević I (eds). Book of abstracts of the International Scientific Symposium "What have we learned about the consequences of the COVID-19 pandemic?" IANUBIH: Sarajevo, 2021

3. Bašić-Kes V: COVID-19 in neurology. In: Sinanović O, Hasanović M, Pajević I (eds). Book of abstracts of the International Scientific Symposium "What have we learned about the consequences of the COVID-19 pandemic?" IANUBIH: Sarajevo, 2021

4. Bevanda M: COVID-19 and gastrointestinal complicatons. In: Sinanović O, Hasanović M, Pajević I (eds). Book of abstracts of the International Scientific Symposium "What have we learned about the consequences of the COVID-19 pandemic?" IANUBIH: Sarajevo, 2021

5. Cheng VC, Lau SK, Woo PC \& Yuen KY: Severe acute respiratory syndrome coronavirus as an agent of emerging and reemerging infection. Clin Microbiol Rev 2007; 20(4):660-94. doi: 10.1128/CMR.00023-07. PMID: 17934078; PMCID: PMC2176051

6. Fazlibegović E: COVID-19: cardiologic disorders. In: Sinanović O, Hasanović $M$, Pajević I (eds). Book of abstracts of the International Scientific Symposium "What have we learned about the consequences of the COVID-19 pandemic?" IANUBIH: Sarajevo, 2021

7. Gajić $O$ : International critical care collaboration during COVID-19 pandemics. In: Sinanović O, Hasanović $M$, Pajevic I (eds). Book of abstracts of the International Scientific Symposium "What have we learned about the consequences of the COVID-19 pandemic?" IANUBIH: Sarajevo, 2021

8. Galijašević $S$ : The role of oxidative stress in $S A R S-C o V-2$ : possible mechanism. In: Sinanović $O$, Hasanović $M$, Pajevic I (eds). Book of abstracts of the International Scientific Symposium "What have we learned about the consequences of the COVID-19 pandemic?" IANUBIH: Sarajevo, 2021

9. Gorbalenya AE, Baker SC, Baric $R$ et al.: Coronaviridae Study Group of the International Committee on Taxonomy of Viruses: The species Severe acute respiratory syndrome-related coronavirus: classifying 2019-nCoV and naming it SARS-CoV-2. Nat Microbiol 2020; 5:536-544. doi:10.1038/s41564-020-0695-z. Epub 2020 Mar 2. PMID: 32123347; PMCID: PMC7095448

10. Hasanović $M$ \& Pajevic I: Health consequences of employees engaged in healthcare during the COVID-19 pandemic. In: Sinanović $O$, Hasanović $M$, Pajević I (eds). Book of abstracts of the International Scientific Symposium "What have we learned about the consequences of the COVID-19 pandemic?" IANUBIH: Sarajevo, 2021

11. Hasukić S: The laparoscopic surgery: technique, ergonomic and specifies in the time of COVID-19 pandemic. In: Sinanović $O$, Hasanović $M$, Pajević I (eds). Book of abstracts of the International Scientific Symposium "What have we learned about the consequences of the COVID-19 pandemic?" IANUBIH: Sarajevo, 2021
12. Jadad AR \& O'Grady L: How should health be defined? BMJ 2008; 337:1361-1364

13. Jakovljevic $M$, Bjedov $S$, Jaksic $N$ \& Jakovljevic I: COVID-19 Pandemia and Public and Global Mental Health from the Perspective of Global Health Securit. Psychiatr Danub 2020; 32:6-14

14. Jakovljevic $M$ \& Jakovljevic I: Sciences, arts, and religions: The triad in action for empathic civilization in Bosnia and Herzegovina. Psychiatr Danub 2021; 33(Suppl 3):S235-S252 - special edition Science, Art and Religion $2021 ; 1: 5-22$

15. Jakovljevic M: Promotion of the mental health and fighting against COVID.19 pandemic and infodemic. In: Sinanović O, Hasanović M, Pajević I (eds). Book of abstracts of the International Scientific Symposium "What have we learned about the consequences of the COVID-19 pandemic?" IANUBIH: Sarajevo, 2021

16. Javed A: Mental health challenges during COVID-19 pandemic. In: Sinanović O, Hasanović M, Pajević I (eds). Book of abstracts of the International Scientific Symposium "What have we learned about the consequences of the COVID-19 pandemic?" IANUBIH: Sarajevo, 2021

17. Jašović-Gašić $M \&$ Cvetić T: Mental health challenges during COVID-19 pandemic. In: Sinanović $O$, Hasanović M, Pajević I (eds). Book of abstracts of the International Scientific Symposium "What have we learned about the consequences of the COVID-19 pandemic?" IANUBIH: Sarajevo, 2021

18. Kes P: Acute kidney injury in patients with COVID-19. In: Sinanović O, Hasanović $M$, Pajević I (eds). Book of abstracts of the International Scientific Symposium "What have we learned about the consequences of the COVID-19 pandemic?" IANUBIH: Sarajevo, 2021

19. Kurjak A: Is the COVID-19 pandemic the end of happy globalization - what was the scientific response? In: Sinanović O, Hasanović M, Pajević I (eds). Book of abstracts of the International Scientific Symposium "What have we learned about the consequences of the COVID-19 pandemic?" IANUBIH: Sarajevo, 2021

20. Leonardi F: The Definition of Health: Towards New Perspectives. Int J Health Serv 2018; 48:735-748

21. Mesihović-Dinarević S: Postcovid-19 in children evaluation of immunological and coronary artery status. In: Sinanović O, Hasanović M, Pajević I (eds). Book of abstracts of the International Scientific Symposium "What have we learned about the consequences of the COVID-19 pandemic?" IANUBIH: Sarajevo, 2021

22. Mesihovic-Dinarevic $S \&$ Ščić T: Post-coronavirus disease 2019 children in Sarajevo-Lessons learnt? J Health Sciences 2021; 11:93-97

23. Muftić M: Post-COVID-19 syndrome - rehabilitation. In: Sinanović $O$, Hasanović $M$, Pajević I (eds). Book of abstracts of the International Scientific Symposium "What have we learned about the consequences of the COVID-19 pandemic?" IANUBIH: Sarajevo, 2021

24. Nikic M: The COVID-19 pandemic - call to conversion and return to God: a view from the perspective of Catholic theology. In: Sinanović O, Hasanović M, Pajević I (eds). Book of abstracts of the International Scientific Symposium "What have we learned about the consequences of the COVID-19 pandemic?” IANUBIH: Sarajevo, 2021

25. Radmanović S: COVID-19 pandemic - shepherd challenges for Orthodox church. In: Sinanovic $O$, Hasanović M, Pajević I (eds). Book of abstracts of the 
International Scientific Symposium "What have we learned about the consequences of the COVID-19 pandemic?" IANUBIH: Sarajevo, 2021

26. Sinanović O: Long-term neuropsychiatric consequences of SARS-CoV infections. Psychiatr Danub 2021; 33(Suppl 3): $S 309-S 317$

27. Sinanović $O$ : Association of sense of smell and taste disorders with SARS-CoV-2 infection. In: Sinanović O, Hasanović M, Pajević I (eds). Book of abstracts of the International Scientific Symposium "What have we learned about the consequences of the COVID-19 pandemic?" IANUBIH: Sarajevo, 2021

28. Sinanović O, Muftić $M$ \& Sinanović S: Covid-19 pandemia: neuropsychiatric comorbidity and consequences. Psychiatr Danub 2020; 32:236-244

29. Sinanović $O$, Hasanović,M \& Pajević I: The Book of Abstracts of the International Scientific Symposium "What have we learned about the consequences of the COVID-19 pandemic?" IANUBIH: Sarajevo, 2021. https://ianubih.ba/2021/10/22/medjunarodni-naucnisimpozij-sta-smo-naucili-o-posljedicama-covid-19pandemije-knjiga-sal

30. Seljubac S: COVID-19 pandemics: a test or punishmentIslamic perspective. In: Sinanović O, Hasanović $M$, Pajevic I (eds). Book of abstracts of the International
Scientific Symposium "What have we learned about the consequences of the COVID-19 pandemic?" IANUBIH: Sarajevo, 2021

31. Smajić J: COVID-19: respiratory disorders. In: Sinanović $O$, Hasanović M, Pajević I (eds). Book of abstracts of the International Scientific Symposium "What have we learned about the consequences of the COVID-19 pandemic?" IANUBIH: Sarajevo, 2021

32. Stanojevic M: Mother and newborn during the COVID-19 pandemic: between Scilla and Charybdis. In: Sinanović $O$, Hasanović M, Pajević I (eds). Book of abstracts of the International Scientific Symposium "What have we learned about the consequences of the COVID-19 pandemic?" IANUBIH: Sarajevo, 2021

33. Trkanjec Z: COVID-19 and Parkinson's disease. In: Sinanović O, Hasanović M, Pajević I (eds). Book of abstracts of the International Scientific Symposium "What have we learned about the consequences of the COVID-19 pandemic?" IANUBIH: Sarajevo, 2021

34. Umakanthan S, Sahu P, Ranade AV, Bukelo MM, Rao JS, Abrahao-Machado LF, Dahal S, Kumar $H \& K v$ D: Origin, transmission, diagnosis and management of coronavirus disease 2019 (COVID-19). Postgrad Med J 2020; 96:753-758. doi:10.1136/postgradmedj-2020138234. Epub 2020 Jun 20. PMID: 32563999

\section{Correspondence:}

Academician Osman Sinanovic

Medical Faculty, University of Tuzla, Univerzitetska 1, 75000 Tuzla

Medical School, University Sarajevo School of Science and Technology

Hrasnička cesta 3a, 71210 Sarajevo, Bosnia and Herzegovina

E-mail: osman.sinanovic1@gmail.com 